\title{
Lords of the Square Ring: Future Capital and Career Transition Issues for Elite Indigenous Australian Boxers ${ }^{1}$
}

\author{
Megan Stronach \\ Daryl Adair \\ University of Technology, Sydney
}

\begin{abstract}
In Australia a serious and widely documented statistical gap exists between the socio-economic circumstances of the country's Indigenous and non-Indigenous populations. Areas of divergence include life expectancy, health, housing, income, and educational opportunity and employment. This has made entry into an occupation or vocation problematic for some Aboriginal people. While sport has provided opportunities for a small number of talented Indigenous athletes, it has rarely been a pathway to lifelong prosperity. This paper contends that as a result of overreliance on an abundant bank of physical capital, Indigenous Australian boxers are particularly vulnerable to potential occupational obsolescence should their bodily assets erode more quickly than envisaged. Utilising an interpretive phenomenological approach, the paper examines retirement experiences of fourteen elite male Indigenous Australian boxers; the goal of this research is to understand their post-sport career decision making. In this respect, Pierre Bourdieu's concepts of habitus, capital and field are utilised to frame and interpret the capacity of Indigenous boxers to develop sustainable career pathways - future capital - during their time as elite athletes. In terms of career transition and retirement planning, boxers' engagement with education and vocational training is typically restricted to occupations that complement their sense of physical capital. While this limitation has been observed among boxers from various ethnocultural backgrounds (Hare, 1971; Ramos, 2010; Weinberg \& Arond, 1969), it is particularly noticeable among non-white boxers (Hare, 1971) and, in the context of the present study, Indigenous Australian athletes. These 'Lords of the Square Ring' remain largely unaware or removed from the possibility of pursuing career pathways beyond those that draw upon or accentuate their physicality.
\end{abstract}

\section{Introduction}

On 13 February 2008, Australian Prime Minister Kevin Rudd made a national apology to members of the Stolen Generations. ${ }^{2}$ As part of this apology, Rudd pledged that his Government would lead a new, national effort to close the gap between Indigenous and non-Indigenous Australians. He referred, in particular, to "the gap in health, in housing, in educational opportunity and attainment, in employment. And the obscenity of the seventeen-year gap in life expectancy” (Rudd 2009). The 'Closing the Gap’ campaign targets, amongst other issues, the 17 year life expectancy gap between Indigenous and non-

\footnotetext{
${ }^{1}$ The authors acknowledge the foundational work of Peter Corris (1980).

${ }^{2}$ The forced removal of Aboriginal and Torres Strait Islander children from their families was official Australian government policy from 1909 to 1969. Governments, churches and welfare bodies all took part, with the power to remove children without parental consent and without a court order. These children became known as the Stolen Generations. Today many of these people still struggle with issues of identity and deep feelings of hurt.
} 
Indigenous Australians. As a result, the matter of lower Indigenous socioeconomic conditions has quickly become a mainstream concern in Australia, although it ought to be conceded that Indigenous disadvantage is hardly new, having been a feature of Aboriginal lives since the impact of colonial settlement.

With the 'closing the gap' vision as a background, this paper evaluates Aboriginal circumstances in the context of an arena in which they appear to have flourished in recent years - elite sport. There are three key domains in which Aboriginal athletes have not only excelled, but been statistically over-represented in recent years - boxing, rugby league and Australian Rules football. This paper focuses singularly on the first of these with the rationale that, while Indigenous NRL and AFL players have begun to receive significant attention from researchers (i.e. Hallinan \& Judd 2009; Adair \& Stronach 2010), the same cannot be said of Aboriginal boxers. The paper is particularly concerned about how Indigenous sportspeople prepare for life beyond elite-level boxing.. It examines the retirement experiences of fourteen elite Australian boxers and, in keeping with the 'closing the gap' theme, does so in the context of the longstanding socioeconomic disadvantage of Indigenous Australians. The paper considers systemic structural inequalities in the areas of education and employment, and their long-term ramifications for Indigenous athletes, despite recently released statistics (ABS 2008a) showing slightly improved levels of schooling and employment of Indigenous people in Australia.

The paper frames these questions by deploying notions of habitus, capital and field as articulated by Pierre Bourdieu (1984). By associating these concepts with elite level boxing in Australia, we question how they influence the capacity of Indigenous boxers to develop sustainable career pathways during their sporting careers. Specifically, we test the proposition that as a result of an over-reliance on their perceived abundant bank of physical capital, combined with limited financial planning, vocational training or education, Indigenous boxers tend to be largely unprepared for life beyond sport. That may mean that the long-term education or vocational training of these athletes is sacrificed for the sport of boxing. This lack of career planning beyond sport is what the authors have termed an absence of future capital - again linking deliberately with Bourdieu and his notions of social, cultural and economic capital. Finally, the paper seeks to determine whether post-sport career choice for this group of elite athletes is mediated by factors relating to their Indigenous heritage.

The study concludes that Indigenous boxers are particularly vulnerable to a deficiency of future capital owing to a preoccupation with their sport life and the virtual exclusion of alternative, non-physical, postsport career paths. In the idiom of sport psychology, this is termed athletic identity foreclosure (Brewer et 
al. 1993), leading to potential occupational obsolescence should a sportsperson's bodily assets erode more quickly than envisaged (e.g. by serious injury). The following section surveys and analyses the academic literature relevant to the paper and then summarises and evaluates Bourdieu's (1984) concepts of habitus, capital and field.

\section{Literature Review}

Career transition and retirement from sport

International research consistently indicates that retirement from elite-level sport may be a potentially difficult, even prolonged and traumatic experience (Lavallee \& Wylleman 2000; Mihovilovic 1968; Taylor \& Ogilvie 2001). Studies on retirement from elite-level sports have shown that many athletes encounter serious economic difficulties, loss of contact with teammates, they miss the camaraderie of the team, have decreased life satisfaction, suffer depression, lose self-esteem, have a greater probability of marriage breakdown, and may engage in pathological behaviours such as suicide, crime and substance abuse (Butt \& Molnar, 2009). They may also experience zeteophobia, otherwise known as anxiety about career decision making (Lavallee et al. 1995). While some athletes find the challenges of their retirement overwhelming and may experience a crisis, others report a positive transition with very few problems (Coakley, 1983). It has been suggested that these peculiarly contrasting experiences are merely a reflection of the idiosyncratic nature of career termination which is characterised in the same way as any transition by a complex interaction of personal and situational factors (Lavallee \& Robinson 2007). However, there is consensus among researchers that career transition planning is likely to make the path to retirement more manageable and successful than might otherwise be the case (Anderson \& Morris 2000; Petitpas \& Champagne 1988).

In sport, an important concept known to influence career transition is known as athlete identity (AI). The concept was initially developed by theorists writing within the discipline of sport psychology (Eldridge 1983; Heyman 1986; Rosenberg 1981). Brewer et al. (1993) defined AI as the degree to which an individual identifies with their role as an athlete. AI is important in this study as: (a) it is considered to be a major factor impacting on adjustment to termination from a sport playing career; (b) significant relationships between AI and zeteophobia have been identified by researchers (Albion \& Fogarty 2003); and (c) athletes found to be most likely to have career and adjustment difficulties were young males in high profile and high income sports, notably the football codes, essentially because of their high levels of AI (Albion \& Fogarty 2003). To date no studies have been undertaken involving AI and elite Indigenous Australian athletes. 


\section{Indigenous contribution to boxing in Australia}

Sport has long played an important social and cultural role in Australia. Aboriginal and Torres Strait Islander peoples are indeed high profile contributors to elite sport in Australia (Korff 2008; Tatz 1995; Thomas \& Dyall 1999), and boxing is one of the most significant to them. In 1987, Tatz reported that there are more Indigenous boxers per head of population than among any other ethnocultural group.

The sport's governing body Boxing Australia Inc. (BAI) cannot provide membership figures to accurately indicate the numbers of Indigenous boxers within their ranks, but the history of boxing in Australia has always had close links with Indigenous communities. For many, it has offered the possibility of a way out of poverty and a means of overcoming racism. BAI reports that many of its members are from a 'working class background' (Boxing Australia 2005). Furthermore, BAI pays tribute to Australia's strong tradition of Aboriginal boxers, fostered early last century by the widely known Jimmy Sharman boxing troupe, which originated in 1910. Many Aboriginal boxers commenced their careers in the Sharman tents (Oliver 2006).

There exists a growing body of research about the recruitment of Indigenous athletes into professional sport (AFL 2008; Boxing Australia Inc 2008; Campbell 2008). The rich history of Aboriginal Australians in boxing is also well documented (Broome, 1980, 1995; Corris 1980; Mooney \& Ramsland 2008; Tatz 1987). However, little is presently known about their adjustment to life after sport, except for the high profile case of former World Boxing Champion and 1969 Australian of the Year, Lionel Rose. During his career Rose earned more money than any other Australian fighter. However, when he retired in 1971, Rose entered a downward spiral of heavy drinking and minor criminal convictions. He also spent most of his money - in his own words, on ‘wine, women and song' (Tatz 2009).

Australian boxers have won silver and bronze medals at Olympic Games and produced numerous professional world champions. However, Australia is yet to produce an Olympic boxing gold medalist: this is now a major objective of amateur boxing officials (Boxing Australia 2005). Professional boxing is, of course, entirely different with its own set of governing bodies, rules and regulations (Oliver 2006).

BAI's boxing talent identification program, originally entitled 'Lords of the Ring', in partnership with the Australian Institute of Sport (AIS), targets young Indigenous athletes using the expertise of the National Talent Identification and Development Program (NTID). The program offers residential scholarships based at the AIS. Four scholarship positions are dedicated to developing Indigenous athletes in different weight categories (Boxing Australia Inc 2008). This provides excellent opportunities for up-and-coming 
champions both within the sport itself, but further, to a wide range of athlete services provided by the AIS - including education and career planning.

Socio-economic factors

In the $21^{\text {st }}$ century, Aborigines and Torres Strait Islanders, once the sole custodians of the Australian continent, constitute less than three per cent of the national population. The pernicious legacy of colonialism remains with Indigenous disadvantage evident across virtually every socio-economic indicator (Adair \& Stronach, 2010 ). Aboriginal people have, as examples, significantly lower life expectancy than other Australians, ${ }^{3}$ much higher levels of unemployment, ${ }^{4}$ considerably lower levels of education and income, ${ }^{5}$ and are vastly over-represented in the nation's prisons. ${ }^{6}$ At the time of the 2006 Census (see Figure 1 below), the top three occupations for Indigenous males were Labourers (30\%), Technicians \& Trade Workers (19\%) and Machinery Operators and Drivers (14\%). Non-Indigenous males were more likely to have occupations as Technicians \& Trade Workers (23\%), Professionals (18\%) and Managers (16\%) (ABS, 2008b).

\section{Figure 1: Occupation by Indigenous Status, Males, 2006}

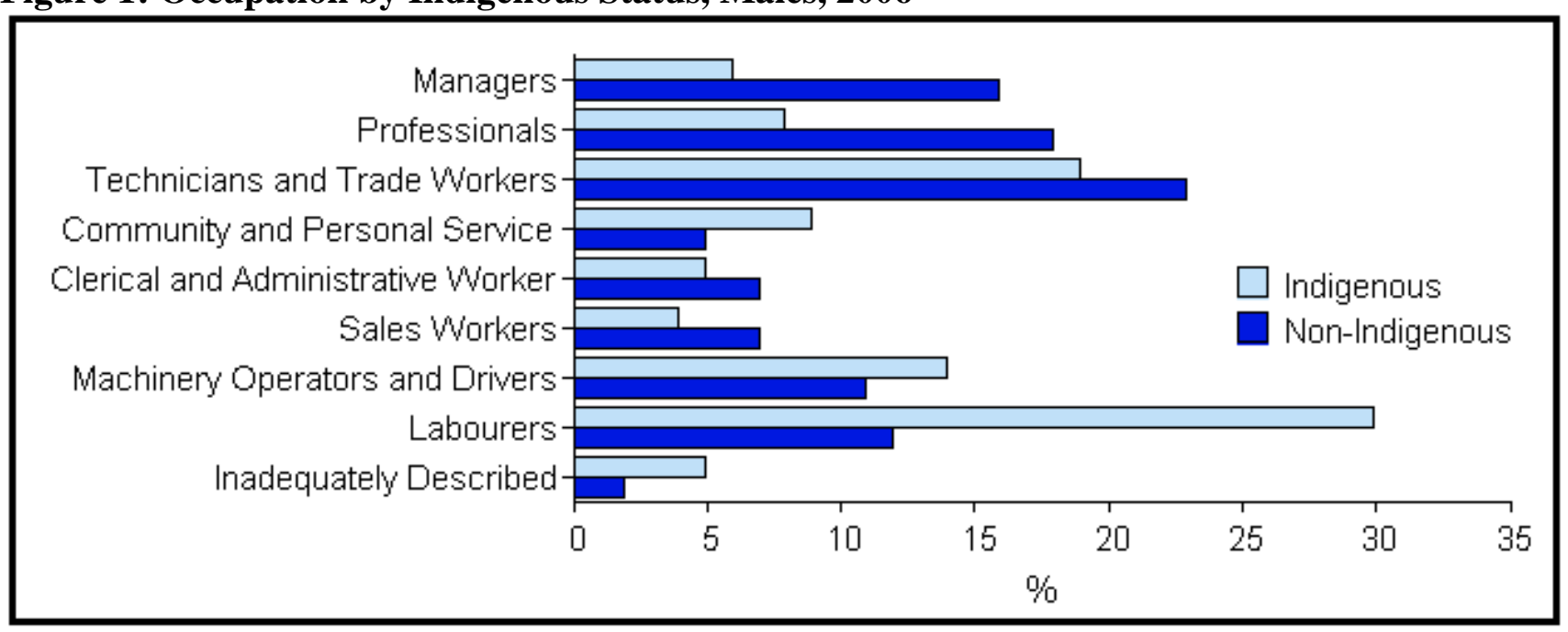

(Source: Indigenous Community Profiles, Australia, 2006 Census).

\footnotetext{
${ }^{3}$ Australian Bureau of Statistics figures for 2005-7 indicate that life expectancy of Indigenous men is 11.5 years lower than for non-Indigenous men, while life expectancy of Indigenous women is 9.7 years lower than for nonIndigenous women (Statham, 2010).

${ }^{4}$ In 2001 the unemployment rate for Indigenous Australians was $20.0 \%$, compared to $7.2 \%$ for non-Indigenous Australians (ABS, 2004).

${ }^{5}$ For example, 39\% of Indigenous students stayed on to year 12 at high school, compared with $75 \%$ for the total Australian population (ABS, 2004). Both high unemployment and low levels of education have impacted the economic circumstances of Indigenous people. In 2002, the average household income for Indigenous Australian adults was $60 \%$ of the non-Indigenous average (ABS, 2005).

${ }^{6}$ Australian Bureau of Statistics figures for 2004 indicate that "Indigenous persons were 11 times more likely to be in prison compared with non-Indigenous persons", and that in 2003 some $20 \%$ of prisoners self-identified as Indigenous (ABS, 2005).
} 
Researchers (Gorman 2004; Naish 2008) have recently provided systematic evidence to indicate that some retired Indigenous athletes have struggled to find suitable employment after their sport career had finished, and that they faced challenges of coping with a new life beyond sport and its athletecentredness. For Indigenous athletes, then, the prospect of retirement from sport involves a particularly urgent need, during their athletic career, for sports organisations to provide professional development opportunities and resources for effective transition to a life beyond sport.

\section{Conceptual Framework: Bourdieu’s formula}

Bourdieu's (1984) theory is written as ‘(Habitus x Capital) + Field = Practice’ (Johnson 2006). In this paper the formula will be utilised to frame the social practices that formulate identity and influence the development of future capital by Indigenous boxers within a wider context of familial, occupational and institutional arrangements (McGillivray \& McIntosh 2006). There will be a particular focus on their engagement (or lack thereof) with educational discourses. Bourdieu's (1984) theory assists with the analysis of responses from participants and in the presentation of the researchers' findings.

Several authors have argued that Bourdieu's (1984) work is very relevant for understanding the dynamic social practices found within sport. For example, Wacquant's (1995) work focused on social structuring and bodily capital among professional fighters in an American metropolis. Moreover, McGillivray and McIntosh (2006), as well as McGillivray, Fearn and McIntosh (2005), have explored the circumstances in which young Scottish footballers perceived their sport as the fulcrum of their lives, thereby committing their whole selves to an occupation that, at best, provided them with short-term occupational and financial security. In each of these studies the social practices of young athletes were theorised using Bourdieu’s (1984) formula for social practice.

Habitus is a concept that seeks to explain the dispositions that influence individuals to become who they are, and yet also includes the conditions of that existence (Bourdieu 1990). Bourdieu describes the habitus as a set of durable dispositions that are carried with, and which work to shape, “attitudes, behaviours and responses to given situations” (Webb et al. 2002, p. 114). As Webb puts it, the habitus is not "something one has, like knowledge that can be brandished, but something one is" (Webb et al. 2002, p. 114). In this respect it is “unconscious and unthinking” (McGillivray \& McIntosh 2006, p. 373) and absorbed unwittingly, based on what may be called an "unreflective routinisation” (McGillivray \& McIntosh 2006, p. 373). Thus the habitus acts to implant certain cultural behaviours such as habits, 
beliefs, values, tastes, bodily postures, feelings and thoughts that Bourdieu argued were socially produced in individuals (Johnson 2006).

The second element, capital, can be best understood as "currency tradable within a specific field" (McGillivray \& McIntosh 2006, p. 374). Within any field the dominant form of capital in circulation governs what is of value. For the investigation of the social positions occupied by Indigenous boxers, two forms of capital - cultural and physical - are especially important. Possessing the desired cultural capital conferred by the educational field normally enhances an individual's opportunities for employment (Bourdieu, 1984). However, in the sport of boxing, we argue that physical capital and the associated embodied competence (speed, skill, strength) are accorded greater value than the cultural capital associated with formal educational discourses (Wacquant 1995). This is understandable in a sport like boxing, which has traditionally attracted athletes ‘from a working class background’ (Boxing Australia 2005) with modest educational experiences and aspirations.

Finally, the third element of Bourdieu's formula for social practice is the field, defined as "a structured social place with its own rules, schemes of domination, and legitimate opinions” (Johnson 2006, no page number). Bourdieu (1990) likened a field and the practices therein to knowing the 'rules of the game' or 'how the game is played'. But within those rules, individuals may use a variety of strategies to 'play the game' or take advantage of opportunities that come their way. The field of boxing has an active relationship with habitus and capital, and can play a crucial role in defining social practices and the relative value of capital within. Thus it may be argued that the field of boxing constructs, promotes and reinforces a particular cultural habitus within which certain forms of capital are valued more highly (McGillivray \& McIntosh 2006). Boxing emphasises the importance of physical capital - (e.g. bodily care and maintenance) over its cultural (educational) counterpart (McGillivray \& McIntosh 2006). This may not be problematic per se in order for boxers to compete successfully, but it may become problematic in the long-term lifespan of these athletes when their physical assets begin to erode, for example, as a consequence of age or injury.

Bourdieu's concept of habitus has been critiqued as being deterministic - that it limits an individual to reproduce only what they know (Johnson 2006). However, according to Reay (2004): “[habitus] carries within it the genesis of new creative responses that are capable of transcending the social conditions in which it was produced” (pp. 434-435). This refers to ‘agency', defined by Webb et al (2002) as “the idea that individuals are equipped with the ability to understand and control their own actions, regardless of the circumstances of their lives” (p. ix). 


\section{Methodology}

For this research, an interpretive phenomenological approach was utilised. Phenomenology allows investigators to understand and describe the ways in which individuals reflect on and experience their lifeworld (Langdridge 2008, emphasis in original). The present study allows for the voices of Indigenous Australian boxers to be heard by enabling the study participants to construct narratives detailing the range of experiences that shape(d) their sports career and their 'lives-after-sport'. However, the current study has a desire to do more with the data than just "describe things in their appearing” (Langdridge 2008, p. 1135) as this seems to offer little potential for critique or the possibility of re-conceptualising the phenomenon being studied (Habermas 1971). This goal of change accords with a conceptual framework known as the transformative paradigm, first articulated by Mertens (2007), which encourages reformist agendas through the identification of stakeholder needs and targeted research responses. In the context of the present study, the transformative paradigm demands deployment of a critical 'lens' for interpreting the situations, circumstances and problems of Indigenous boxers, and how these might be improved. A purposive convenience sampling method was used in which subjects were selected because of some important characteristics. As with other non-probability sampling methods, purposive sampling does not produce a sample that is representative of a larger population, but it can be exactly what is needed - in this case research into a clearly defined and relatively limited group (Patton 2002). In this study, fourteen elite Indigenous Australian boxers were interviewed. Our interest in the athletes extended beyond the current crop of young boxers to incorporate the opinions of more established and experienced senior professionals, some of whom have been retired for up to 20 years, but have maintained links with the sport. Participants were all elite performers but variously amateur or professional, and either currently in sport or retired. Initial contact with the sample group was made with the assistance of key stakeholders, notably personnel from BAI and the AIS. Several participants were contacted by using the social networking utility Facebook: respondents could choose to respond (or otherwise) to online inquiries about whether they would like to participate in the current research project. On two occasions, the Koori Mail (Australia’s national Indigenous newspaper) published articles about this research project, inviting readers to make contact with the lead author, if they wished to participate. All of these means were effective in reaching athletes who subsequently formed the sample group.

Interview guides were developed for both groups, initially based on issues for investigation established by the literature review, and a preliminary analysis of content was undertaken. Transcripts were read 
through several times, which allowed an early appreciation of topics deemed relevant to the participants. These encompassed athletic careers, post-sport careers, social support resources, athlete career and education programs, and recommendations for future Indigenous sport programs. As time progressed, the interview guides were modified as a greater understanding of the participants' transition from their sport career to their present situations was developed. The interview guides were also informed by suggestions of appropriate methods for questioning Indigenous peoples developed by Australian Family Law Court counsellor Stephen Ralph. He recommended that, due to strong oral traditions of Indigenous peoples, allowing individuals to provide information using a narrative style may be more effective than standard question and answer sessions (Ralph 1997). While the interview process was guided to some degree by the lead researcher, it was less rigid than relying on a formal questionnaire (Denzin \& Lincoln 2005). The semi-structured 'conversation approach' thus became a loose, fluid, and flexible invitation to share information by personal narratives or 'story-telling'.

Interviews were conducted between July and December 2009. A critical approach to narrative analysis was employed, which enabled the lead author to interpret the hidden meanings behind the stories told during interviews. In this process the words of the participants were viewed with both "empathy (understanding tradition) and suspicion (engaging in critique)" (Langdridge 2008, p. 1136). However, at all times the subjects were provided with written copies of their testimony, and they each had opportunities to respond to drafts of the study as they were composed. The input of the boxers at all stages of the research process was therefore very important.

Qualitative data was supplemented by interviewee responses to the Athletic Identity Measurement Scale (AIMS) (Brewer et al. 1993). The AIMS (Brewer et al. 1993) is a short questionnaire, with ten items encompassing social, cognitive, and affective elements of AI, and was administered to boxers within the interview process. The AIMS items tap into the thoughts and feelings derived from athletes' daily experiences. Scores on each item can range from 1-5; therefore the overall score can range from 10-50. Scores on this 10-item scale were averaged to give an indication of respondents' overall level of AI.

The authors of this article are not Indigenous; nor have we been professional athletes. But we have endeavoured, through dialogue with Aboriginal men, to understand how and why they engage(d) with their sport, why boxing matters to them, and how they negotiate(d) their future lives. As mentioned previously, the engagement of the participants in various parts of the study was crucial. This was intended to ensure trustworthiness in the study, with participants engaged as critical members of the research process. All participants whose ‘voices' appear in this study were provided with a draft copy of 
the article, and invited to confirm that their words were accurate, free from hidden meanings and used in the correct context. When discrepancies were found, the lead author communicated and negotiated with the participants until such time that all parties were satisfied that the representations were clear and accurate.

\section{Findings}

These are presented in two interdependent sections, beginning with a presentation of the demographic data, which is then integrated with the interview findings, to produce a synthesised discussion section.

\section{Table 1 Demographic characteristics of participant group}

\begin{tabular}{|l|l|l|l|}
\hline Demographic data. & Current & Retired & Total \\
\hline Professional Boxers & 3 & 4 & 7 \\
\hline Amateur boxers & 4 & 3 & 7 \\
\hline Total & 7 & 7 & 14 \\
\hline
\end{tabular}

The average age of the boxers was 31.21 years, ranging from 18 - 58 years. The average time in boxing at the elite level was 8.36 years, with seven retiring from sport during the past twenty years. Nine are currently - or have been - AIS scholarship holders, and ten have competed at international level (such as Olympic Games, Commonwealth Games, and World Titles).

All the boxers have left school. Currently five are employed in community and personal services (2 personal trainers, 3 youth workers), with two working as labourers. Two boxers are currently unemployed, with one describing his occupation as a labourer, the other as a personal trainer. Two boxers make their living by boxing professionally; both of these want to become personal trainers. One amateur boxer who has recently completed year 12 and one current AIS scholarship holder also intend to become personal trainers. One former boxer receives a disability pension. Eleven boxers were married or in a stable relationship with a partner; three were single. Five had been born in regional areas, four in remote areas and three in urban areas of Australia - all had, at some time in their lives, relocated to larger cities to develop their boxing careers.

\section{Education and work status}

Figure two compares current education and work status for Indigenous, non-Indigenous people and Indigenous boxers. Fewer Indigenous boxers have competed Year 12 than non-Indigenous people, and fewer boxers have a post-school qualification than either Indigenous or non-Indigenous people. There is a much higher unemployment rate for boxers than for Indigenous or non-Indigenous people. 
Figure 2: Education and work status of Indigenous and non-Indigenous persons

\begin{tabular}{|c|c|c|c|}
\hline & $\begin{array}{l}\text { *Indigenous } \\
\text { Persons } 2008 \%\end{array}$ & $\begin{array}{l}\text { *Non- } \\
\text { Indigenous } \\
\text { Persons } 2008 \\
\%\end{array}$ & $\begin{array}{l}\text { Indigenous } \\
\text { Boxers } 2009 \\
\%\end{array}$ \\
\hline \multicolumn{4}{|l|}{ Education } \\
\hline $\begin{array}{l}\text { Highest year of school completed is year } 12 \text { or equivalent } \\
\text { (15-64 yrs) }\end{array}$ & 21.2 & 53.8 & 21.42 \\
\hline $\begin{array}{l}\text { Highest year of school completed is year } 12 \text { or equivalent } \\
\text { (20-24 yrs) }\end{array}$ & 31.3 & 76.2 & 33.33 \\
\hline Has a non-school qualification (15-64 yrs) & 32.9 & 54.3 & 21.42 \\
\hline Has a non-school qualification (25-64 yrs) & 40.2 & 61.3 & 30.00 \\
\hline \multicolumn{4}{|l|}{ Work(a) } \\
\hline Labour force participation rate (15-64 yrs) & 64.5 & 76.5 & 61.53 \\
\hline Unemployment rate (15-64 yrs) & 16.6 & 5.0 & 38.47 \\
\hline
\end{tabular}

Figure three compares the education levels between 26 AIS athletes who responded to surveys from 2003 to 2007 in a five-year evaluation of the Athlete Career and Education program (ACE), the sport career transition program delivered by the AIS and associated institutions (Australian Institute of Sport 2009) and the sample group of fourteen boxers. A huge $71 \%$ of boxers did not complete year 12, compared to $4 \%$ of the total population of AIS athletes. While some boxers have completed a certificate or diploma, none have gone on to complete a university degree, compared to $42 \%$ of AIS athletes who hold an undergraduate or post-graduate degree.

Figure 3: Education levels of AIS athletes and boxers

\begin{tabular}{|l|l|l|}
\hline & $\begin{array}{l}\text { AlS athletes }(n=26) \\
2003-2007 \%\end{array}$ & $\begin{array}{l}\text { Boxers }(n=14) \\
2009 \%\end{array}$ \\
\hline Still in high school/college & 11 & 0 \\
\hline Didn't complete high school/college & 4 & 71 \\
\hline Completed high school/college & 35 & 28 \\
\hline Certificate or diploma & 8 & 21 \\
\hline Degree & 38 & 0 \\
\hline Post graduate degree & 4 & 0 \\
\hline *Source: Fraser, Albion \& Fogarty (2008) Evaluation of the Athlete Career and Education Program \\
\hline
\end{tabular}

\section{Interview findings}


Data analysis led to the establishment of six themes that best articulated the social practices of boxers as they prepare for life-after-sport. Close links between these themes and the elements in Bourdieu's formula are apparent. As a set of durable dispositions, the habitus of these boxers appears in some of their values, including the importance of their Indigenous heritage, kinship and community obligations; and an 'unconscious and unthinking' intense self belief as a 'natural' athlete. The group appears to value physical capital, confirmed by a strong AI and a reliance on boxing to improve quality of life, at the expense of educational capital such as schooling and academic success. As the field of boxing imposes the 'rules of the game', risk-taking behaviours and a perceived lack of control become apparent. These elements form dynamic relationships that work to develop future capital, to a greater or lesser extent, illustrated in Figure four.

Figure 4: Links between emerging themes and Bourdieu's formula in the development of future capital.

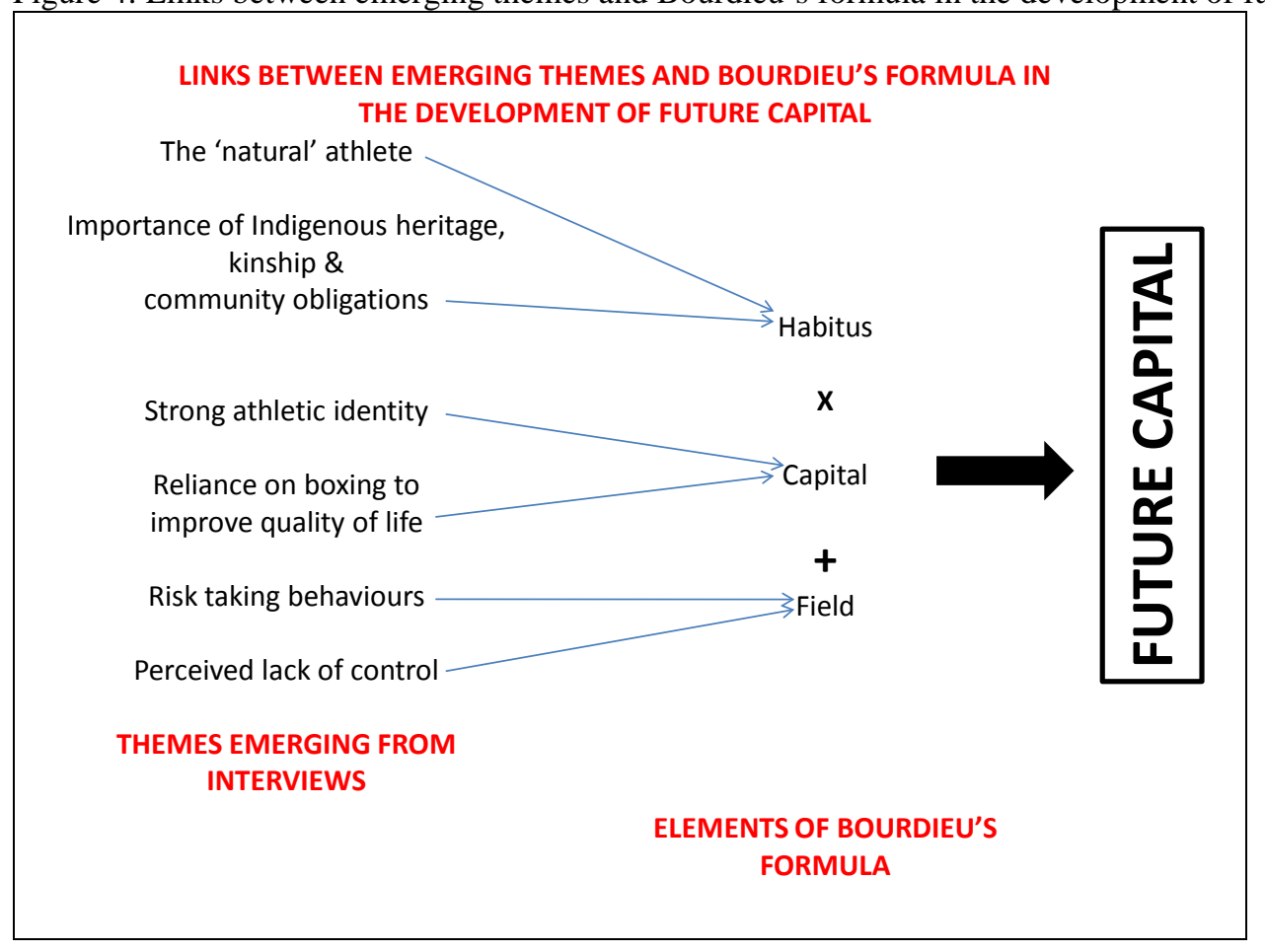

\section{Discussion}

For these athletes, retirement from sport has the potential to be very problematic. Boxers typically love their sport, and the prospect of no longer being able to compete is painful. This is consistent with many recent studies. 'Nick' (retired amateur boxer) expressed feelings shared by many:

(Retirement) was tragic, it broke my heart, it was the worst thing that happened to me in my life, or that I'd ever done, ever done. And I still feel emotional about it now; still do a bit of crying. I could have turned professional, but to me professional is nothing, I'd never set 
myself for professional boxing. I wanted to be the first Australian to win an Olympic gold medal - I'd had that dream since I was a 14 year old kid.

\section{Habitus - the 'natural order'?}

The notion that the habitus is 'unconscious and unthinking, based on unreflective routinisation' may help to explain many of the values and social practices apparent in the development of future capital by the sample group of Indigenous boxers. Two themes relating to their Indigenous backgrounds were evident in the approach of the boxers towards their sport careers.

First, the boxers viewed their decision to develop a career in boxing as the norm, or the 'natural order of things'. Many have grown up with an 'unconscious awareness' that entering a career in boxing was automatic, virtually a 'given' based on some genetic trait or familial link, so that they would eventually become irretrievably linked to the sport.

You know yourself, you can go anywhere in Australia, any school in Australia, the best athlete is what? The best sportsman is what? Indigenous people. They're gifted, high fighters, running, speed, more balance, rhythm, timing - they're gifted ('Jerry', retired professional boxer).

If they want to kick a football, they've already got the upper hand, because they're aboriginal. Aboriginal people are naturally good at sport. It's just a known thing - they are naturally good at it - they've got the upper hand, they've just got to put their mind to it and they can do whatever they want ('Ian', current professional boxer).

The comments of 'Jerry' (who retired almost twenty years ago) and 'Ian', a current professional boxer, demonstrate a widely and still-held belief that, as Indigenous people, these athletes are 'naturally' talented, 'naturally' suited to the sport, and thus they fully expect to perform and achieve at high levels. Indigenous boxers enter the sport with an almost unthinking acceptance of all that it entails. This tendency was noted in the prescient work of Godwell (1997) who investigated Aboriginal men's involvement in rugby league. Godwell (1997) railed against beliefs that ascribed to Indigenous people innate, natural or genetically inherited physical abilities that 'predisposed' them, as a group, to be good at sport. He observed that this had been popularised by media superlatives for Aboriginal players, with descriptors like 'black magic', which in recent times has been supplemented by new rhetoric, such as ‘wizardry’ (Adair \& Stronach 2010 ). Similarly, Hallinan and Judd (2009) observed a perception by Indigenous Australian Rules footballers that their excellence in the sport was due to a set of "unique prescribed characteristics and traits determined biologically in their 'Aboriginal' genes and culturally in their ‘Aboriginal’ knowledge of time/space” (p. 2369). In his study of African-American boxers, 
Wacquant (1995) noted the same inclination, describing a "non-thetic quasi-organismic commitment to the sport ... operating beneath the level of discourse and consciousness” (p. 88).

Of course, sometimes there are other factors that generate this strong self-belief. 'Pete', a retired professional boxer, when asked if his life had been better due to his involvement in the sport was somewhat scathing in his response:

I don't think that needs an answer. I'm sorry but I am a fighter. I was $21 / 2$ months premature, so I've been a fighter from day one, so you know ... I love boxing.

The second set of 'unconscious and unthinking' values is a staunch pride in their Indigenous heritage, along with kinship and community obligations. Indigenous communities are described as "thick with kinship and embedded relationships, obligations, and traditions” (Pearson 2007, p. 24). These are fundamental concepts for Indigenous Australians but their complexity may be beyond the comprehension of many non-Indigenous people. Again 'Pete’ (retired professional boxer) explained.

And it's family first always, sharing, care for your people and respect. And our life - it's about reciprocation. And we have an obligation to teach our children to follow the rules rules are fine for everyone.

In a very poignant account, 'Ian’ tells how his parents had made significant sacrifices to further his boxing career. In his mind, what his parents gave him most of all was love and security. After the death of his father, there is no doubt in 'Ian's mind that he must now assume the mantle of responsibility for his family.

It was a 5 hour round trip and then we lived a further half an hour out of town, so we had to drive an hour each night - half an hour in, then train, then half an hour out, 5 nights a week. And tell me, when you have no money, how can you do that? And they never let me know, they never let me know - I bet there were times they had no money in the bank, absolutely none, but we always had food on the table, and I always felt safe. I always thought we were rich - I thought - I always had the best gloves, and never missed a tournament ... so now it's more of a payback thing, my father passed away, so I'm the man of the house now, and I've got to provide for my mother and my little sister ('Ian', current professional boxer).

The values that these boxers bring to their sport are formulated 'beneath the level of discourse and consciousness', to the extent that sometimes the athletes are not cognisant that they hold them or that their day-to-day actions are influenced accordingly. 'Jerry’ (retired professional boxer) contemplated his Indigeneity, and the sub-conscious level where actions are formulated, concluding:

'I think it's there in some way, some things you do, you realise it’s Indigenous...' 


\section{Capital - valuing the physical}

For highly motivated, young Indigenous men, the allure of boxing, even in the 21st century, remains in its potential to make money, thus appearing as a way out of poverty, low socio-economic situations, or broken families. Medals, honour and glory are also powerful motivators. Only two amateur boxers interviewed stated they did not wish to turn professional, and all but two of the professional boxers had started in the amateur ranks. For some, the goal is to become the first Australian to win the elusive Olympic gold medal. For others, a world championship is not beyond their ability.

\footnotetext{
If I could be the first person to win a gold medal for Australia, I could only imagine how much money I would get. You'd make history, you know, you'd be famous overnight, so that's my aim, that's my goal ... at the end of the day it all comes back to money. You know, if you're good at your sport and you get good money for it - why wouldn't you? ('Dennis', current amateur boxer).

It was the Olympic Qualification year for Beijing Olympics, and I was fortunate enough to finish second that year - I got a silver medal. So I got all the way to the gold-medal round and got second which is good. And now, yeah, well, I want to win a world title ('Jack', current professional boxer).
}

To say that boxing is a body-centered world is an understatement. It is an undeniable fact that boxers cultivate their own bodies in order to impose maximum damage to that of their opponent, but at the same time they show almost obsessional levels of care in developing their bodies, and enormous pride in the results.

\footnotetext{
I'm a very very exciting fighter - I'm a guy that whenever I was in the ring, there'd be something happening ('Jerry', retired professional boxer).

I'm good on my feet - so it's technical - I'm very good technically, I don't use a lot of energy in the ring ('Anders', retired amateur boxer).
}

These comments are not made to brag or to sing their own praises; rather, they are personal truisms, reflecting how athletes value physical capital. That is, they believe, how things 'should be' for Indigenous boxers who have worked long and hard. Further, valuing physical capital is perhaps manifested by high levels of AI. Current boxers in this sample recorded relatively high measures on this scale (range 33 - 49, mean score 37.85), which were higher than scores reported by Fraser et al. (2008) (mean score 35.95) by athletes studied in their five-year evaluation of the ACE program at the AIS. Many authors (Brewer et al. 1993; Lavallee et al. 1995; Lavallee et al. 1997) have described positive consequences associated with strong AI on athletic performance. A strong AI may have lasting psychological benefits for the athlete such as the development of a salient self-identity, a positive effect on athletic performance and a higher likelihood of long-term participation in exercise, with corresponding 
health and fitness benefits (Brewer 1993). These high levels of AI exhibited by boxers appear to be enhanced by their love of the sport and the strong the attraction of the field. 'Dennis' likens the attraction of boxing to an 'addiction', while 'Wills', having left the sport, laments his loss and describes how his body still reacts sub-consciously as it did when he was in training.

It's hard to keep away from it. I've been doing it for so long, it's an addiction. An addiction. An addiction. When I train I feel good, when you walk around fit you feel good, like on top of the world, you can do this and you can do that ('Dennis', current amateur boxer).

I miss it - when I walk around I walk on my toes. If I'm walking in a crowd I'm walking little boxing moves, just to walk through the crowd - like footwork you know? ('Wills', retired amateur boxer).

The Field - rules of the game

Athletes with high levels of AI may place too much emphasis on sport, this leading to psychological and physical limitations in other contexts. A high AI may also prompt some individuals to engage in sport or exercise activity to the extent that their physical health is jeopardised (Brewer et al. 1993). Boxers acknowledge the damage and the risks involved with the sport, but engage in risk-taking practices nevertheless. These risks may be considerable, leading to debilitating injuries and even death. They include fractures of the carpus, metacarpus and thumb, nose and jaws, acute osteo-articulatory stress, scratched or detached retina and brain damage (Wacquant 1995). The common practice of 'making weight' (with one boxer reporting a need to shed seven kilos in the 24 hours prior to weigh-in) exposes boxers to 'adverse cardiovascular function electrical activity, thermal regulation, renal function and electrolyte balance' (Johns 2002, p. 122). By risk-taking behaviour, boxers are not only jeopardising their long-term physical well-being, but also their capacity to develop sustainable career pathways or future capital, whilst in the sport.

You've always got to think about the risks. But if you train properly, and you do everything properly, you limit those risks, and as long as you're fully prepared then the chance of something happening are a lot smaller... If you do things properly, most of the time you don't get hurt. Everybody takes risks every day; it's just about limiting those risks as much as possible ('Kim', current professional boxer).

I was losing too much weight, overtraining, dehydration, so I inflamed the right side of my heart and my kidneys collapsed on me. So I gave up for a year to try to fix that and get my body back in shape again ('Anders', retired amateur boxer).

You know, boxing is a sport where there is a chance of brain damage, and all that stuff, so I don’t want to be in there longer than I should be ('Ian' current amateur boxer).

One serious consequence of such risk-taking behaviour is called dementia pugilistica (commonly known as the 'punch-drunk' syndrome), which may result in cognitive impairment, unsteady gait, slurred speech, 
foot-dragging and memory loss. ${ }^{7}$ The problem is that the deterioration may not become obvious immediately, and the capacity to assess one's physical state also declines at a similar rate, so that the more damage a boxer sustains, the less he is able and willing to perceive and acknowledge it (Wacquant 1995). Boxers in this study demonstrated an awareness that they may not be able to opt out of the sport on their own terms, fearing that the magnetic allure of boxing may overwhelm the commitments they had made to themselves and significant others, thus compromising their planned exits.

I'm going to give myself 3 to 4 years, but I'm sort of like, if I can - like if I won an Australian title then I'm looking at - well, all I'd have to do is win a regional title, like the Asia-Pacific Title, then I could have a shot at a World Title, you know what I mean? (laughs) It's gone from here, like oh if I could reach that pinnacle then I'd think why not have a shot, if I could, at a major title ('Kris', current professional boxer).

Bourdieu and Wacquant (1990) have referred to this situation as symbolic violence, which, they suggest, was not a physical form of violence but rather being treated as inferior, stereotyped, limited in their social mobility and aspirations. One commentator described the situation: "We were getting sick and tired of ... promoters treating them like ‘cannon fodder'. They don't look after them” (Key stakeholder \#3, personal interview, 30 September 2009). But this is not what many of these boxers perceive - to them these risktaking practices are the 'rules of the game'.

Eventually, however, some boxers recognise that they have been denied resources (lack of educational schemes and support in professional boxing), their aspirations restricted (abrupt dismissals from AIS programs when they fail to produce results), their futures compromised by an ongoing, almost singular commitment to the field, with the result that they have lost control over their own careers.

In the end I thought I was, I was bein' ah...sort of... you see I started to think they didn't have the same interest in me as I thought they did - they wasn't as genuine ('Billy', retired professional boxer).

To make it worse the AIS pretty much said, oh you lost, thanks, thanks for your time, see you later, have fun ('Kim', current professional boxer).

You look at what are the intentions and whose best intentions are they really looking out for - are they looking out for me, or are they only looking out for themselves ('Jack', current professional boxer).

Perhaps this behaviour is best explained by a line in the iconic song 'The Boxer': 'a man hears what he wants to hear and disregards the rest' (Simon \& Garfunkel 1968). Conversely, Wacqant (1995) associates it with the 'pugilistic' field and the aim therein to produce a specific form of capital. Even though the

\footnotetext{
${ }^{7}$ Some of the boxers interviewed in this study by the lead author did appear to display one or more of the symptoms of the 'punch-drunk' syndrome. The researcher is, however, not qualified to diagnose such a condition. 
spectacle of the devastated boxer is all around them, boxers seem to manage to screen out awareness of physical danger and impairment, with trainers, managers and coaches colluding to support an illusion that "injury does happen, but ... to others, those who do not train right, those who do not sacrifice, or who do not dedicate themselves to the game as they should” (Wacquant 1995 p. 86). To this extent, then, boxers are complicit in their own oppression and disempowerment owing to their acceptance of the established social order to which they are subjected.

\section{Post-sport careers}

Within the field of boxing, young Indigenous athletes make significant sacrifices to pursue their dream of a career within the sport, preparing to exchange their 'bodily capital' for a livelihood. However, intense involvement with sport at the elite level tends to place significant restrictions on levels of educational attainment (Gearing 1999; McPherson 1980). Interviewee data from the present study also suggest that levels of educational attainment are unduly affected by boxing careers. Boxers justify their decisions to value the physical over cultural (educational) capital, reflecting the pressures they face to commit to their sport rather than to academic studies, albeit with some regret.

I think my love and passion for the sport, you know, I've given my life to the sport. Like if I'd gave enough effort into school work, maybe in studies and relationships it would have been great, but boxing has been my only thing that I've ever give all to... ('Tom', retired professional boxer)

School? - The Commonwealth Games fell in my HSC (Higher School Certificate) year and I put all my efforts into Commonwealth Games so school got missed out. I didn’t care about the school marks and results and now I wish I had good marks because then I would have something to fall back on. As I said I've been boxing since I was 10, and that's all I know, I don't know anything else ('Dennis', current amateur boxer).

Although many boxers commenced Vocational Education and Training (VET) courses whilst on scholarship with the AIS, few actually completed these qualifications. In fact, of the seven athletes expressing an interest in personal training as a career pathway, only one has finished the required qualification course (Certificate III in Fitness), and this was done in the years following his retirement.

(At the AIS) I started to do some fitness courses, some different courses like that. I never actually got to finish one I was - I really wanted to finish. It was Certificate III in Fitness, yeah, I started that down in Canberra but because of training commitments and travelling and stuff like that I didn't get to finish it ('Kim', current professional boxer).

Kim's comment illustrates the ongoing lure of boxing and the subsequent downgrading by most of the interviewees of educational or vocational qualifications. Similar situations have been noted in other research studies. Hickey and Kelly (2008) have described a "lack of engagement” (p. 477) shown by 
Australian Rules footballers in higher education programs, largely due to the intense demands of elite level professional sport. In a study of Australian rugby union players, Price (2007) demonstrated that involvement in elite rugby does not facilitate the accomplishment of developmental tasks that would be required later in life. Finally, McGillivray and McIntosh (2006) concluded that for professional Scottish footballers, “despite increased awareness and availability of educational opportunities, players’ engagement with educational discourses is, at best, an instrumental means-end and outcome-based one” (p. 371).

The high levels of AI noted in this group suggest that some may be vulnerable to athletic identity foreclosure and difficulties with sport career termination and career decision-making. A fascination with personal training noted among these boxers seems telling. It is clearly the most popular career or career choice, with seven of the boxers stating that they either do work or have worked in the field, or that it is their primary career choice. Arguably it is indicative of the concept of AI foreclosure where individuals see themselves almost exclusively in the role of athlete, and that their 'natural' domain is in the world of the physical.

The required training, the VET Certificate III in Fitness,: 'prepare(s) you to work in any capacity on the gymnasium floor with confidence’ (Fitness Institute Australia, 2009). In a study of sport coaches, Lavallee et al. (1997) provided evidence to suggest that for some individuals, the continued involvement in a sport-based career may ease their transition from being an athlete by allowing their sport-related identities and social support systems to remain intact. For boxers, however, a coaching role does not appeal, because, as one interview respondent put it, “coaches do it because they love it, not to make money” ('Anders', retired amateur boxer). It seems that a career as a personal trainer is the next best thing, allowing a continued involvement with the sport, a prolongation of AI and potentially producing a livelihood, at least for as long as the boxer's physical health allows him to 'work on the gymnasium floor'. Personal training offers the possibility of retaining a sense of physical capital, and maximizing the physical literacy developed during a boxer's career.

The other major career pathway noted with this group is in community welfare and youth work. One Registered Training Organisation (RTO) that works specifically with Indigenous athletes to prepare them for life-after-sport, AFLSportsready, has reported that 70\% of Indigenous trainees in their programs have expressed a desire to return to work in Indigenous communities, in areas such as community development, local government, and sport development (Naish 2008). 
Two of the athletes in the present study have chosen careers in Community Welfare or youth work.

Several others expressed their desire to support disadvantaged Indigenous youth and communities.

Gorman (2008) has noted that traditionally most of the community work that current athletes undertake is unseen or unacknowledged, but "there is a heavy emphasis on maintaining links with their communities" (Gorman, cited in Winkler 2008). For these boxers, the opportunity to 'give back' to community was, yet again, part of their habitus, the 'natural order'.

I want to give something back to it, like, I used to fly up to (Northern Australian Indigenous community) and talk to Indigenous kids about drugs, and alcohol - and to give them a dream to carry on with something. I love doing that sort of stuff ('Anders', retired amateur boxer).

\section{Agency}

Bourdieu's (1990) investigations into cultural fields also addressed that 'actors' are equipped with the ability to understand and control their own actions that could alter their cultural trajectories, regardless of the circumstances of their lives. This suggests that strategies may be developed to consider the ways that boxers' identities might be reformulated to broaden their engagement with education, and thus prepare them for sustainable post-athlete pathways during their sport careers, thereby maximising their future capital.

There have been two significant changes in the field of boxing in Australia in recent years: the initiation of the AIS Boxing Program in 1997 (during the lead-up to the Sydney 2000 Olympic Games) and the launch of the National Talent Identification and Development Program (Lords of the Ring) in 2006, which initially targeted Indigenous boxers exclusively. These programs have given scholarship boxers at least some exposure to the ACE program and career counseling whilst at the AIS (Australian Institute of Sport 2009).

As noted previously, boxers who did not complete schooling expressed some regret. However, at the AIS 'Kris' (current professional boxer) demonstrated agency. He saw and grasped an opportunity that came his way:

I wanted to make a change in my life, so I saw the opportunity, the opportunity to study, when I was down in Canberra at the AIS. ... the AIS scholarship came along, I jumped on it. And then I saw all the opportunities when I went there and I was training, working during the day and studying at night. 
Unfortunately, 'Kris’s experience should not be viewed as typical; other interviewees did not engage in education or vocational training during their boxing careers. Due to their habitus or notions of the 'natural order', their high esteem of physical capital and the pressure of the field, it appears that Indigenous boxers typically need assistance in planning both their professional careers and their life-after-sport career pathways. One vital area of need for amateur boxers is as they try to make a transition into professional ranks. Unfortunately, when leaving the confines of amateur boxing, the young boxer is left largely to his own devices, requiring an enormous change in his approach to people around him. As 'Kim' (current professional boxer) commented:

Boxing's the type of sport - in the long part of it, you don't make any money. When you get to the top of it, the elite level, you've got to really make the most of it you really can. There are a lot of opportunities. It's just a matter of making sure the management do their job.

But preparation for this phase of a boxing career does not form part of a structured program, leaving these athletes ill-equipped to cope. It is essential, therefore, that counselors be available to provide advice about both sport and life-after sport career pathways. Many of the boxers have described their need for culturally appropriate counseling. In the case of Indigenous Australian athletes, this advice should ideally emanate from within their own culture, as one retired sportsman argued (personal interview, 10 October 2009):

\footnotetext{
When an Indigenous person walks into an organisation, whether it be in a sport or anything else - what they bring with them is who they are, everything about family first, and caring and nurturing, and they understand issues, that really nobody else can, no matter how good, or how much goodwill someone may mean. So how can one person know what's in another person's mind if they're not Indigenous?
}

While it may not be feasible, logistically, for Indigenous boxers around Australia to each have access to a counselor with Indigenous heritage, a base line position ought to be that all counselors undergo education in culturally appropriate ways to engage with boxers of varying backgrounds - including Aborigines and Torres Strait Islanders.

\section{Conclusion}

Commentators have argued that elite level sport, despite its profile and financial lure, can be a disempowering environment in the sense that the athlete's life-world is typically dominated by the field overwhelmingly so (Hallinan \& Judd 2009; McGillivray \& McIntosh,2006; Price 2007). This paper has further explored these issues by relating and examining the narratives of elite Australian Indigenous boxers. The paper demonstrates that for this cohort, engagement with education and vocational training 66 
remains generally restricted to occupations that complement their heightened values of physical culture, kinship and community obligation. Thus they remain, by and large, devoid of realistic alternatives within the confines of their habitus. The field of boxing continues to recruit, groom and then exploit these young men athletically, educationally and financially. Boxers are at risk of being quickly discarded once their physical assets are eroded, without having ensured they are fully prepared to enter alternative occupations.

The paper provided an overview of career transition issues and produced an initial exploration into the development of future capital for elite Indigenous boxers. Professional sport for Indigenous people is a subject worthy of continued study for, in many ways, these are individuals who have the opportunity to 'Close the Gaps' in their own lives, and in turn be seen as exemplars for Indigenous people in other occupational spheres.

\section{References}

ABS 2004, 1301.0 Year Book Australia 2004 [Electronic Version]. Retrieved 16 May 2008 from http://www.abs.gov.au/AUSSTATS/abs@.nsf/featurearticlesbyCatalogue/BC6A7187473C6FB6 CA256DEA00053A29?OpenDocument.

ABS 2005, 1301.0 Year Book Australia 2005. Retrieved 31 March, 2010, from http://www.abs.gov.au/ausstats/abs@.nsf/00000000000000000000000000000000/294322bc5648 ead8ca256f7200833040!OpenDocument

ABS 2008a, 4714.0 - National Aboriginal and Torres Strait Islander Social Survey 2008 Retrieved 25 November, 2009, from http://www.abs.gov.au/AUSSTATS/abs@.nsf/productsbyCatalogue/

ABS 2008b, Indigenous Statistics for Schools. Retrieved 30 November 2009, from http://www.abs.gov.au/websitedbs/cashome.nsf/89a5f3d8684682b6ca256de4002c809b/ae2abb19 50921fbfca25758b00123537!OpenDocument

Adair, D., \& Stronach, M. 2010, 'Natural born athletes? Australian Aboriginal people and the doubleedged lure of professional sport', In J. Long \& K. Spracklen (Eds.), Sport and Challenges to Racism, Palgrave MacMillan, London.

AFL 2008, Influence of Indigenous players. Retrieved 15 October, 2008, from http://www.afl.com.au/News/NEWSARTICLE/tabid/208/Default.aspx?newsId=2539

Albion, M. \& Fogarty, G. 2003, Evaluation of the Athlete Career and Education Program, Phase 1 2003, Centre for Organisational Research and Evaluation, University of Southern Queensland, Brisbane.

Anderson, D. \& Morris, T. 2000, 'Athlete Lifestyle Programs', In D. Lavallee \& P. Wylleman (Eds.), Career Transitions in Sport: International Perspectives, Fitness Information Technology, Morgantown, WV.

Australian Institute of Sport 2009, AIS Athlete Career and Education. Retrieved 16 January, 2010, from http://www.ausport.gov.au/ais/scholarships/ais_athlete_career_and_education

Bourdieu, P. 1984 Distinction: A Social Critique of the Judgement of Taste, Routledge \& Kegan Paul, London. 
Bourdieu, P. 1990, The Logic of Practice, Polity Press, Cambridge.

Bourdieu, P. \& Wacquant, L. 1990, An Invitation to Reflexive Sociology, The University of Chigaco Press, Chicago.

Boxing Australia 2005, 2005-2009 Strategic Plan. Retrieved 30 November, 2009, from www.boxing.org.au/documents/StrategicPlan2005-2009finalversionpdf

Boxing Australia Inc. 2008, News. Retrieved 15 October, 2008, from http://www.boxing.org.au/news.html

Brewer, B. 1993, 'Self-identity and specific vulnerability to depressed mood', Journal of Personality vol.61, pp. 343-364.

Brewer, B., Van Raalte, J. \& Linder, D. 1993, 'Athletic identity: Hercules' muscles or Achilles' heel?' International Journal of Sport Psychology vol. 24, pp. 237-254.

Broome, R. 1980, 'Professional Aboriginal boxers in Eastern Australia 1930-1979', Aboriginal History, vol. 4, pp.49-72.

Broome, R. 1995, 'Enduring moments of Aboriginal dominance: Aboriginal performers, boxers and runners', Labour History vol. 69, pp. 171-187.

Butt, J. \& Molnar, G. 2009,' Involuntary career termination in sport: a case study of the process of structurally induced failure', Sport in Society, vol.12, no. 2, pp. 240-257.

Campbell, E. 2008, Relocation stories: Experiences of Indigenous players in the AFL, School of Psychology Faculty of Arts, Education and Human Development, Victoria University.

Coakley, J. J. 1983,' Leaving competitive sport: Retirement or rebirth?' Quest no. 35, pp. 1-11.

Corris, P. 1980, Lords of the Ring: A social history of prize fighting in Australia, Cassel, North Ryde.

Denzin, N., \& Lincoln, Y. S. 2005, The Sage Handbook of Qualitative Research. Sage, Thousand Oaks, CA.

Eldridge, W. 1983, 'The importance of psychotherapy for athletic related orthopaedic injuries among adults', International Journal of Sport Psychology vol. 14, pp. 203-211.

Fitness Institute Australia 2009, Retrieved 7 December, 2009, from http://www.fia.com.au/FIAcourses/programs_fr.html

Fraser, L., Albion, M. \& Fogarty, G. 2008, Evaluation of the Athlete Career and Education Program. Community and Organisational Research Unit, University of Southern Queensland, Brisbane.

Gearing, B. 1999, 'Narratives of identity among former professional footballers in the United Kingdom', Journal of Aging Studies, vol. 13, no. 1, p. 43.

Godwell, D. 1997 'Aboriginality and rugby league in Australia: An exploratory study of identity construction and professional sport', Dep't of Kinesiology, University of Windsor.

Gorman, S. E. 2004, Moorditj magic: The story of Jim and Phillip Krakouer. Unpublished PhD Murdoch University, Perth.

Habermas, J. 1971, Knowledge and Human Interests, Beacon Press, Boston.

Hallinan, C., \& Judd, B. 2009, 'Changes in assumptions about Australian Indigenous footballers: From exclusion to enlightenment', Sport in Society, vol. 12, no. 9, pp. 1220-1235.

Hare, N. 1971, 'A study of the black fighter', The Black Scholar, vol. 3, no. 3, pp. 2-9.

Heyman, S. 1986, 'Psychological problem patterns found with athletes', The Clinical Psychologist no. 39, pp. 68-71.

Hickey, C. \& Kelly, P. 2008, 'Preparing to not be a footballer: higher education and professional sport', Sport, Education and Society, vol. 13, no. 4, pp. 477-494. 
Johns, D. 2002, 'Weight Management as Sport Injury: Deconstructung Disciplinary Power in the Sport Ethic', In K. Young (Ed.), Sporting Bodies, Damaged Selves, Elsevier., Amsterdam.

Johnson, N. 2006, Bourdieu section - habitus. Retrieved 10 May, 2010, from http://academictreatise.blogspot.com/2006/02/bourdieu-section-habitus.html

Korff, J. U. 2008, Aboriginal Indigenous Sport. Retrieved 16 January, 2009, from http://www.creativespirits.info/aboriginalculture/sport/

Langdridge, D. 2008, 'Phenomenology and Critical Social Psychology: Directions and Debates in Theory and Research', Social and Psychology Compass, vol. 2, no. 3, pp. 1126-1142.

Lavallee, D., Gordon, S. \& Grove, J. R. 1995, Athletic identity as a predictor of zeteophobia among retired athletes, Paper presented at the 12th Annual Conference of Counseling Athletes, Springfield, MA, USA.

Lavallee, D., Gordon, S. \& Grove, J. R. 1997, 'Retirement from sport and the loss of athletic identity', Journal of Personal and Interpersonal Loss vol. 2, pp. 129-147.

Lavallee, D. \& Robinson, H. K. 2007, 'In pursuit of an identity: A qualitative exploration of retirement from women's artistic gymnastics', Psychology of Sport and Exercise, vol. 8, no.1, pp. 119-141.

Lavallee, D. \& Wylleman, P. (Eds.) 2000, Career Transitions in Sport: International Perspectives. Fitness Information Technology, Morgantown WV.

McGillivray, D., Fearn, R. \& McIntosh, A. 2005, 'Caught up in and by the beautiful game', Journal of Sport and Social Issues, vol. 29, no. 1, pp. 102-123.

McGillivray, D., \& McIntosh, A. 2006, "'Football is My Life" Theorizing Social Practice in the Scottish Professional Football Field', Sport in Society, vol.9, no. 3, pp. 371-387.

McPherson, B. P. 1980, 'Retirement from professional sport: The process and problems of occupational and psychological adjustment', Sociological Symposium vol. 30, pp. 126-143.

Mertens, D. 2007, 'Transformative paradigm', Journal of Mixed Methods Research, vol. 1, no. 3, pp. $212-$ 225.

Mihovilovic, M. 1968,' The status of former sportsmen', International Review of Sport Sociology, vol. 3, pp. 69-73.

Mooney, C. \& Ramsland, J. 2008, 'Dave Sands as Local Hero and International Champion: Race, Family and Identity in an Industrial Working-class Suburb', Sport in History, vol. 28, no. 2, pp. 299-312.

Naish, C. 2008, General Manager, Commercial Operations, AFL SportsReady, personal communication.

Oliver, P. 2006, What's the score? A survey of cultural diversity and racism in Australian sport, Human Rights and Equal Opportunity Commission, Sydney.

Patton, M. 2002, Qualitative research and evaluation methods (3rd ed.),Sage, Thousand Oaks, CA.

Pearson, N. 2007, 'Through the glass ceiling', The Weekend Australian, 4-5 August, p. 24.

Petitpas, A. \& Champagne, D. 1988, 'Developmental programming for intercollegiate athletes', Journal of College Student Personnel, vol. 29, pp. 454-460.

Price, N. 2007, Game of two halves: preparing young elite rugby players for a future beyond the game. University of Wollongong, Wollongong.

Ralph, R. 1997, 'Working with Aboriginal families: issues and guidelines for family and child counsellors', Australian Institute of Family Studies, vol. 46, pp. 46-50.

Ramos, A. 2010, Retired Boxers Foundation. Retrieved 1 June, 2010, from http://www.retiredboxers.com/whereare.html 
Reay, D. 2004, 'It's all becoming a habitus: Beyond the habitual use of Pierre Bourdieu's concept of habitus in educational research', Special Issue of British Journal of Sociology of Education on Pierre Bourdieu, vol. 25, no. 4, pp. 431-444.

Rosenberg, E. 1981, Professional athlete retirement: Bringing theory and research together, Paper presented at the First Regional Symposium, Vancouver, B.C.

Rudd, K. 2009 The first annual Closing the Gap Report. Retrieved 1 December 2009, from http://www.alp.org.au/media/0209/spepm260.php

Simon, P. \& Garfunkel, A. 1968 The Boxer.

Statham, L. 2010, 'Aborigines have "worst" life expectancy', Sydney Morning Herald, 15 January.

Tatz, C. 1987, Aborigines in Sport, The Australian Society for Sports History Bedford Park, SA.

Tatz, C. 1995, Obstacle race: Aborigines in sport, NSW University Press, Kensington.

Tatz, C. 2009, 'Racism and sport in Australia', Race \& Class Retrieved 30 November, 2009, from http://rac.sagepub.com

Taylor, J. \& Ogilvie, B. (Eds.) 2001, Career termination among athletes (2 ed.), Wiley \& Sons, New York.

Thomas, D. \& Dyall, L. 1999, 'Culture, ethnicity, and sport management: A New Zealand perspective', Sport Management Review, vol. 2, pp. 115-132.

Wacquant, L. 1995, 'Pugs at Work: Bodily Capital and Bodily Labour Among Professional Boxers', Body \& Society, vol.1, no.1, pp. 65-93.

Webb, J., Schirato, T. \& Danaher, G. 2002, Understanding Bourdieu, Sage, London.

Weinberg, S. K. \& Arond, H. 1969 'Occupational culture of the boxer', In J. W. Loy \& K. G. S. (Eds.), Sport, Culture and Society, MacMillan, New York, pp. 443-452.

Winkler, M. 2008, Who is the next Michael Long? Retrieved 25 May, 2009, from http://www.afl.com.au/News/NewsArticle/tabid/208/Default.aspx?newsId=59975 